\title{
Strategie di valorizzazione/rivitalizzazione del patrimonio architettonico storico armeno. II caso studio di Arates
}

\author{
Alessandra Vezzi
}

Abstract

Questa ricerca intende considerare il potenziale della conservazione della memoria locale, attraverso un progetto di ricerca interdisciplinare focalizzato sullo studio di edifici medievali e le relative connessioni territoriali nella regione della Vayots Dzor. Più precisamente localizzato nel caso studio del Monastero di Arates, si pongono le basi per recuperare un patrimonio culturale che potrebbe diventare in futuro, un'occasione di sviluppo per il paese. Le campagne di rilievo condotte hanno permesso di realizzare degli elaborati grafici che documentino lo stato attuale della struttura in stato di rovina. Quindi, attraverso questo materiale, si strutturano due tipi di linee di studio: una sviluppata dal punto di vista progettuale legata alle connessioni interdisciplinari tra vari settori di indagine che lavorano per creare nuove soluzioni progettuali tra territorio e architettura. L'altra strutturata dal punto di vista sociale, con l'utilizzo di nuove tecnologie divulgative come video e realtà virtuale, in modo da permettere una lettura più comprensibile e universale. Lo scopo è quello di sviluppare nuove strategie di incremento gestionale e funzionale delle strutture architettoniche rivitalizzando il patrimonio storico territoriale architettonico armeno.

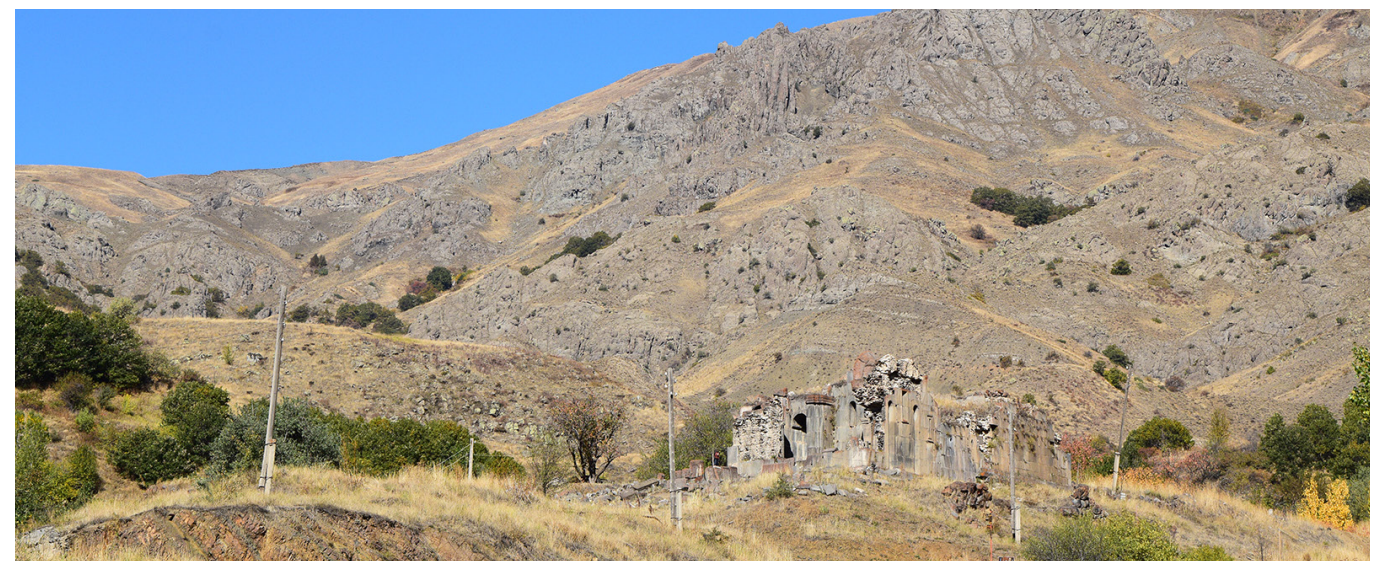




\section{Introduzione}

Dal 20 17, il Dipartimento di Architettura (DIDA) e il Dipartimento di Storia, Archeologia, Geografia Arte e Spettacolo (SAGAS) dell'Università di Firenze collaborano con l'Università di Yerevan in uno studio interdisciplinare sulle strutture medievali armene. II campo di interesse è stato circoscritto alla regione della Vayots Dzor di cui si sta analizzando le strutture militari e religiose di periodo medievale e le relative connessioni territoriali. Tutto ciò per recuperare un patrimonio culturale che siamo persuasi possa essere il propulsore di nuove occasioni di sviluppo per il paese. La conservazione della memoria di questi luoghi è alla base della ricerca. Possiamo distinguere, quindi, una linea di ricerca volta al consolidamento e all'incremento della consapevolezza di quei territori, sia dal punto di vista urbano che da quello strettamente architettonico. In tale ambito presentiamo qui il caso studio di Arates, caso emblematico di un importante centro funzionale di epoca medievale che ad oggi risulta del tutto abbandonato e in disuso. Preso come oggetto di tesi di laurea, il sito presenta infatti tutte le qualità necessarie per realizzare un progetto pilota che inneschi una nuova strategia di rivitalizzazione del territorio attuata attraverso la dislocazione funzionale di alcuni servizi.

\section{II monastero di Arates}

La Vayots Dzor è una regione a sud-est dell'Armenia caratterizzata da valli attraversate da corsi d'acqua come i fiumi Yeghegis, il Martuni e l'Arpa, che è il principale. Lungo le valli dove si svolgono le attività agricole, si trovano i villaggi rurali connessi tra di loro tramite strade o percorsi che caratterizzano la maglia urbana del territorio. Attualmente non tutti possono permettersi l'uso di un'automobile quindi risulta rilevante valutare il tempo di cammino tra i differenti siti e gli eventuali centri di servizio. II concetto del percorrere a piedi in memoria delle strade antiche è mantenuto ancora oggi nei luoghi d'interesse dove, su pannelli informativi, vengono segnalati: la distanza in km, il tempo in ore di cammino e il dislivello tra i due siti più vicini da raggiungere.

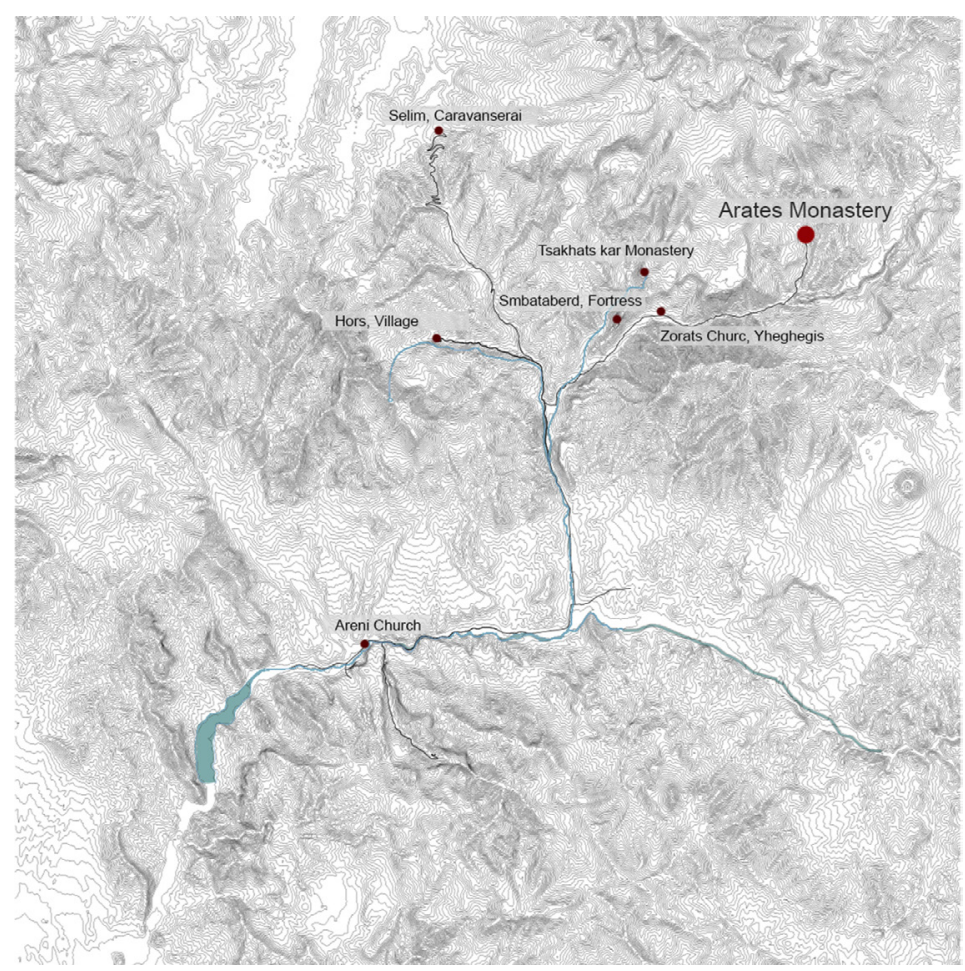


Luogo sacro e meta di turismo, sia locale che straniero, è il Monastero di Arates (figg. 2-5), posto a $2000 \mathrm{~m}$ di altitudine, situato lungo le rive del fiume Martuni a I0,8 km dal villaggio di Yeghegis ( $2 \mathrm{~h}-15 \mathrm{~min}$ di cammino), e $4 \mathrm{~km}$ dal villaggio di Hermon. Tale Monastero fa parte di un villaggio con bassa densità edilizia.

Il complesso architettonico è composto da quattro corpi di fabbrica tra cui due chiese, S. Sion e S. Astvatsatsin (Santa Madre di Dio), un gavit antistante quest'ultima, ormai distrutto, e una zona intermedia voltata (fig. 6). Le chiese sono poste, da nord a sud, l'una accanto all'altra. S. Sion datata da Paolo Cuneo [I], fra il IX e il X secolo rappresenta il primo nucleo della fabbrica. Essa è costituita da un'aula monoabsidata con un'unica navata, due cappelle laterali che affiancano l'abside e concludono esternamente l'impianto con un muro rettilineo. Questa tipologia conferma la presenza di una comunità monastica che si sviluppa, durante il primo millennio, con la collaborazione del villaggio vicino di Hermon sviluppando un'economia basata sull'agricoltura e l'allevamento. In seguito alla sua crescita, la struttura viene adattata con l'aggiunta di nuovi corpi di fabbrica.

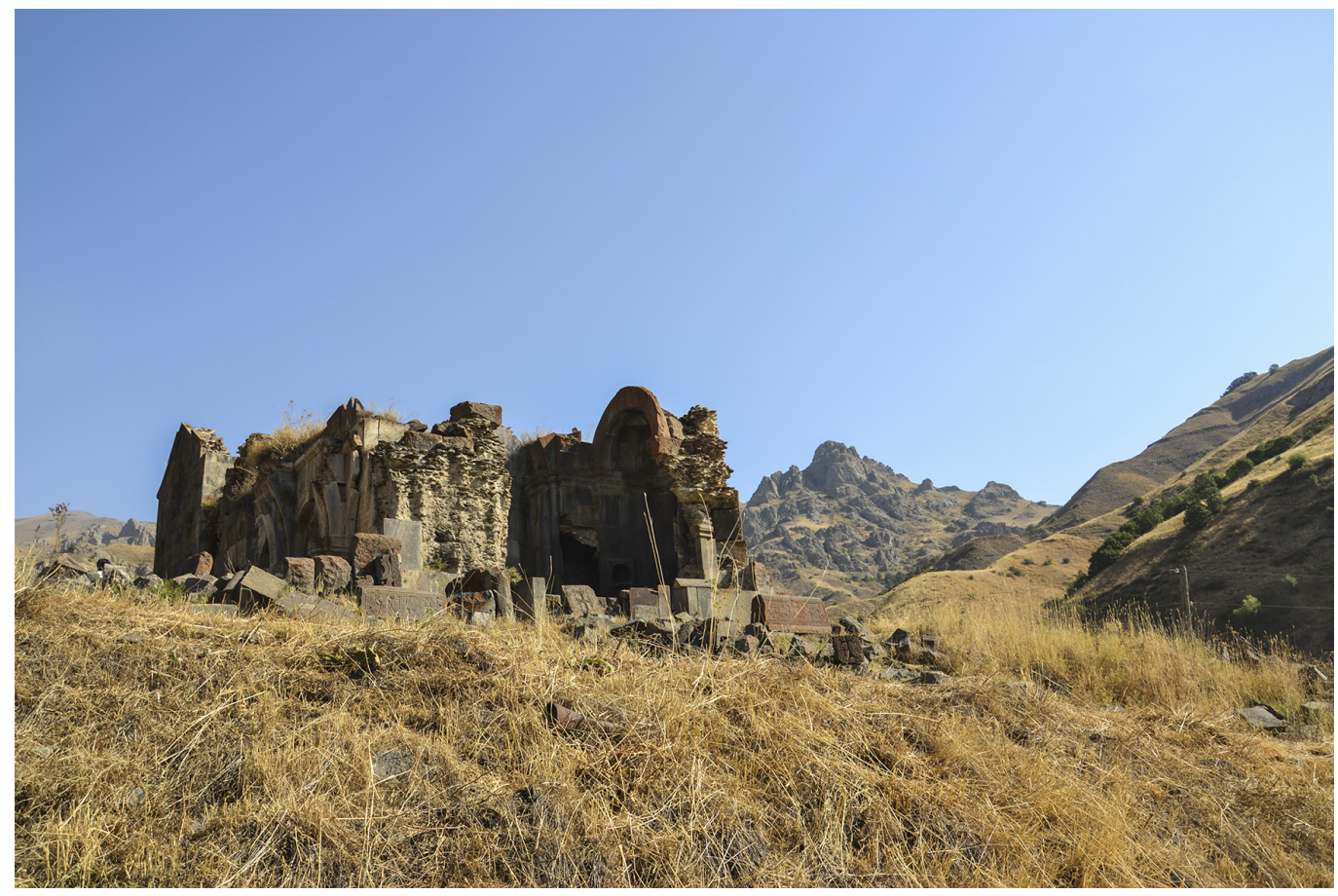

II successivo ampliamento è quello di $\mathrm{S}$. Astvatsatsin datata tra la metà del $\mathrm{XI}$ secolo, una chiesa a sala centrale cupolata. Le volte che un tempo sostenevano la cupola, poggiavano su una coppia di pareti, rimaste intatte, addossate ai lati nord e sud della chiesa stessa. L'abside è fiancheggiata da due cappelle, una delle quali è rimasta quasi completamente integra mentre dell'altra resta solo la base con il primo filare di lastre. Gli ingressi alle chiese sono rivolti ad ovest.

II gavit, la cui costruzione risale al 1270 durante il periodo della dinastia degli Orbelian, è lo spazio antistante la chiesa di S. Astvatsatsin con la funzione di accoglie la comunità laica dei fedeli che durante le celebrazioni, non potevano accede allo spazio sacro. Inoltre, rappresenta una struttura, ad oggi crollata, al tempo sorretta su pilastri con al centro un'apertura ad oculo nella copertura. Nella sua pavimentazione lastricata si trovano lapidi sepolcrali. La zona intermedia, infine, posta tra le due chiese ha una pianta irregolare quasi quadrata collegata a due cappelle sul lato est. II complesso, attualmente, si trova in stato di rovina e gran parte del monastero è crollata lasciando a vista la struttura interna del sacco murario. 


\section{Connessioni progettuali}

Le campagne di rilievo condotte dalla facoltà di Architettura di Firenze nel 2018 e nel 2019 [2] hanno permesso di realizzare degli elaborati grafici che documentano lo stato attuale della struttura (figg. 7, 8). II rilievo diretto e le campagne fotografiche hanno permesso una ricostruzione del manufatto che è servita e servirà da supporto per tutte le analisi di cui il monumento necessita ancora. Lavorando in un team multidisciplinare il lavoro condotto è stato infatti strutturato e finalizzato ai differenti settori di indagine: archeologico (per la lettura stratigrafica delle fasi costruttive), architettonico (per la comprensione stessa delle matrici progettuali e come supporto per una proposta di conservazione e riqualificazione progettuale) e strutturale (per analizzarne la suscettività sismica e attuare le giuste azioni di intervento).

Tramite piante, prospetti e sezioni nella scala appropriata è stata resa accessibile un'architettura sulla quale possono essere applicati studi specialistici approfonditi. Si può parlare quindi di connessioni progettuali tra i vari ambiti di studio che insieme contribuiscono ad avere un risultato accurato e significativo sull'edificio preso in esame.

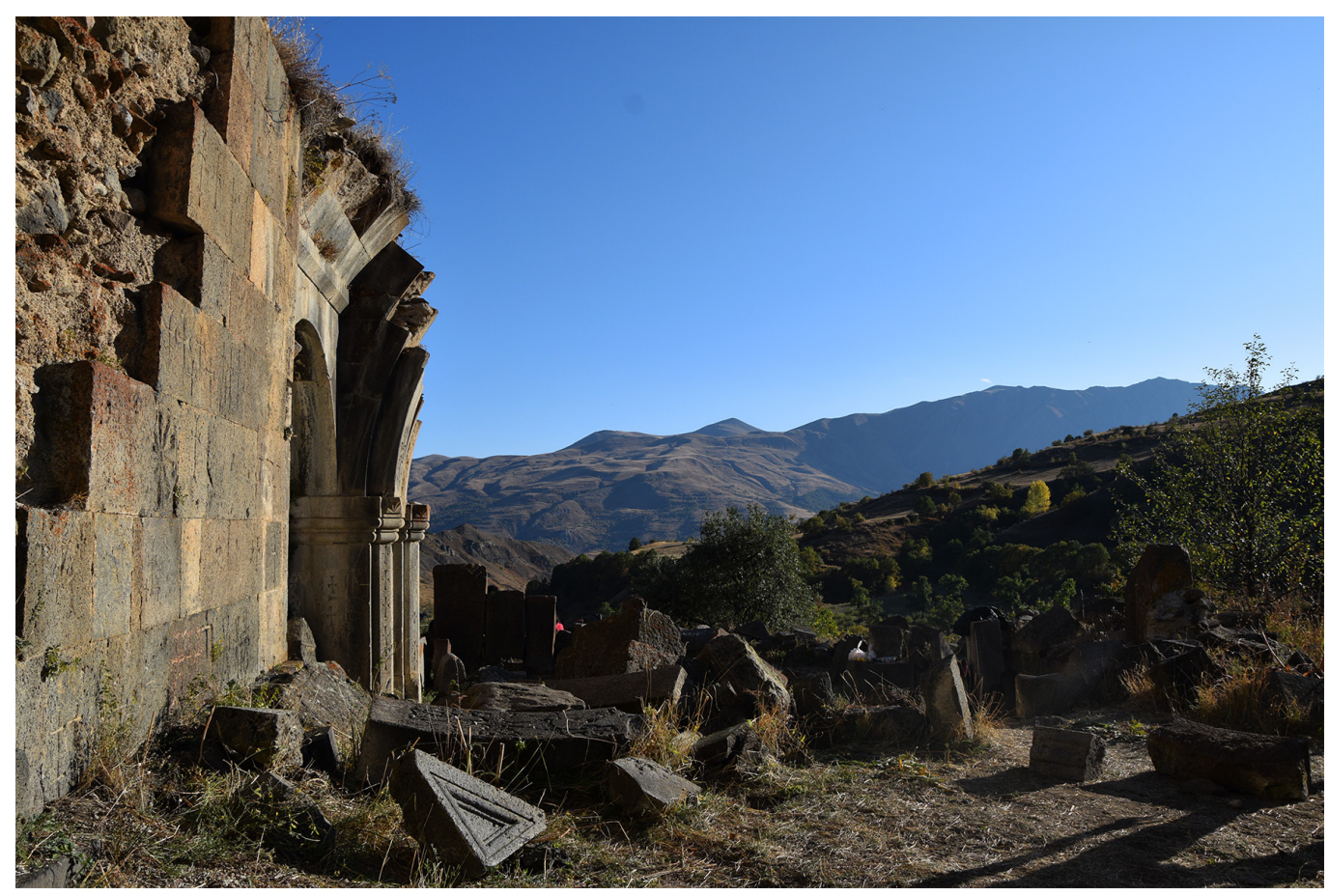

Tutte queste informazioni forniscono una base per un eventuale progetto di consolidamento e di restauro fino a giungere a soluzioni progettuali compositive che affondano le radici nella storia del luogo. Parlando di quest'ultime va presa in considerazione la cultura massiva architettonica degli edifici sacri, caratterizzata da conci in pietra squadrata del colore delle montagne circostanti nelle quali si confonde la struttura esistente. Osserviamo in tale contesto l'importanza di utilizzare i materiali del luogo, come il legno e la pietra proveniente dalle cave circostanti.

Riuscire a dialogare con i vari dislivelli del terreno che circondano il costrutto e lo caratterizzano significa trovare un dialogo con lo stesso genius loci che deve aver ispirato il costruttore medievale. In questo modo si cerca di alimentare la memoria del luogo perché conservi quello che è già esistente ma, allo stesso tempo, attraverso un nuovo progetto di rifunzionalizzazione, si cerca di rinnovare e rendere fruibile un'architettura che possa superare il tempo riacquistando il suo ruolo di attrattore funzionale. 


\section{Connessioni sociali}

Rimanendo nello specifico campo della comunicazione di un progetto, evidenziamo che la rappresentazione dello spazio architettonico, solitamente espresso attraverso disegni bidimensionali, è ottimale per gli esperti di settore ma non per gli individui esterni che hanno difficoltà nella visualizzazione dello spazio. In un contesto di divulgazione preliminare nell'elaborazione dei dati di ricerca è importante quindi utilizzare tecnologie [3], come modelli tridimensionali territoriali e del singolo edificio che possano permettere una lettura più comprensibile in grado di coinvolgere tutti i tipi di osservatore attraverso un nuovo approccio informativo.

Per la realizzazione del modello 3D del territorio circostante viene utilizzato un file shp contenete le curve di livello necessarie poste su un unico piano, alle quale vengono attribuite le altezze una volta importante nel software QGis. Mentre per il modello 3D dell'edificio da analizzare è fondamentale utilizzare l'integrazione tra rilievo diretto e indiretto (fotogrammetria digitale) a seconda dell'attrezzatura disponibile e la difficoltà di accesso ai siti, ottenendo un modello mesh o nurbs se ricostruito geometricamente. Infine, tramite un sistema di coordinate dell'architettura presa in esame è possibile integrare i due modelli tridimensionali. In questo modo si ottiene un modello più adatto agli scopi divulgativi pur mantenendo le caratteristiche tecniche scientifiche.

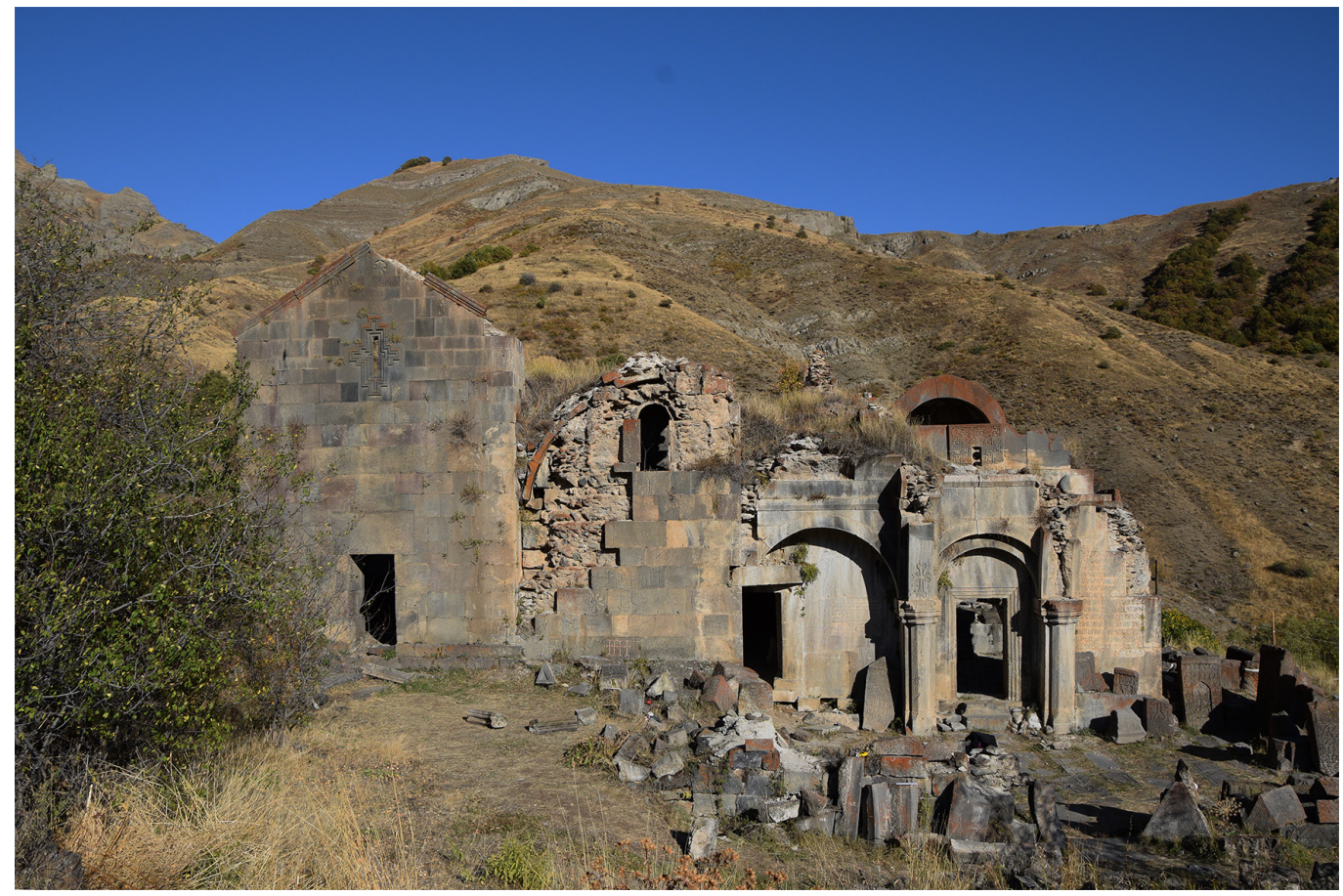

Lo scopo è quello di diffondere i modelli attraverso due sistemi di visualizzazione come: il video e la realtà virtuale. Attraverso il video lo spettatore è guidato da un'animazione tramite diverse inquadrature scelte dal regista che identificano un percorso: inquadrature più ampie e ambientali, quando si tratta di mostrare il territorio e inquadrature più puntuali quando si vuole indicare più nel dettaglio un edificio architettonico. Nella realtà virtuale $(V R)$, invece, il punto di vista è quello dell'osservatore che viene inserito in uno scenario creato al computer, e quindi virtuale, diventando il protagonista di una nuova realtà. 
Fig. 5. Inquadramento territoriale del Monastero d Arates (in rosso).
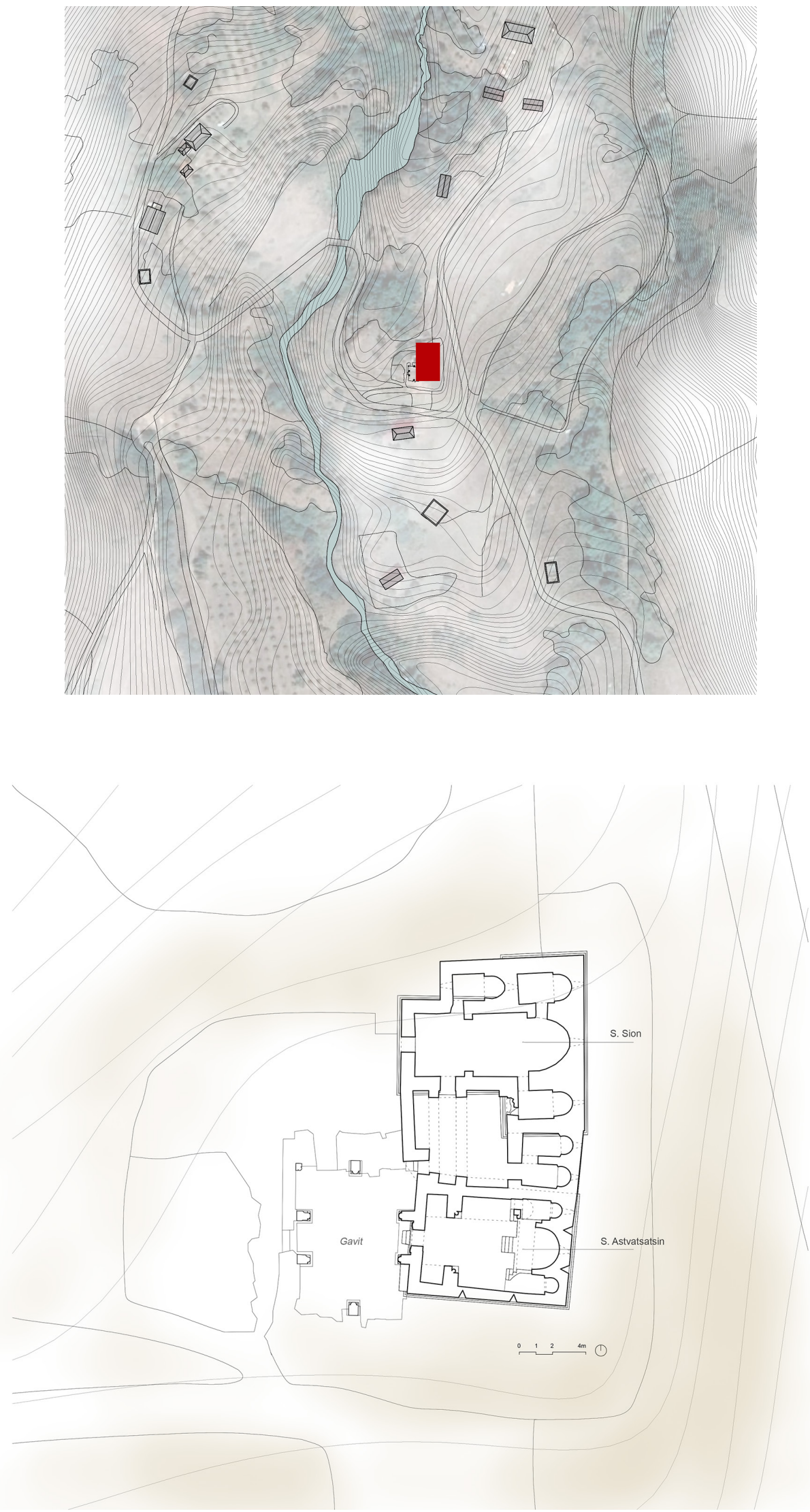

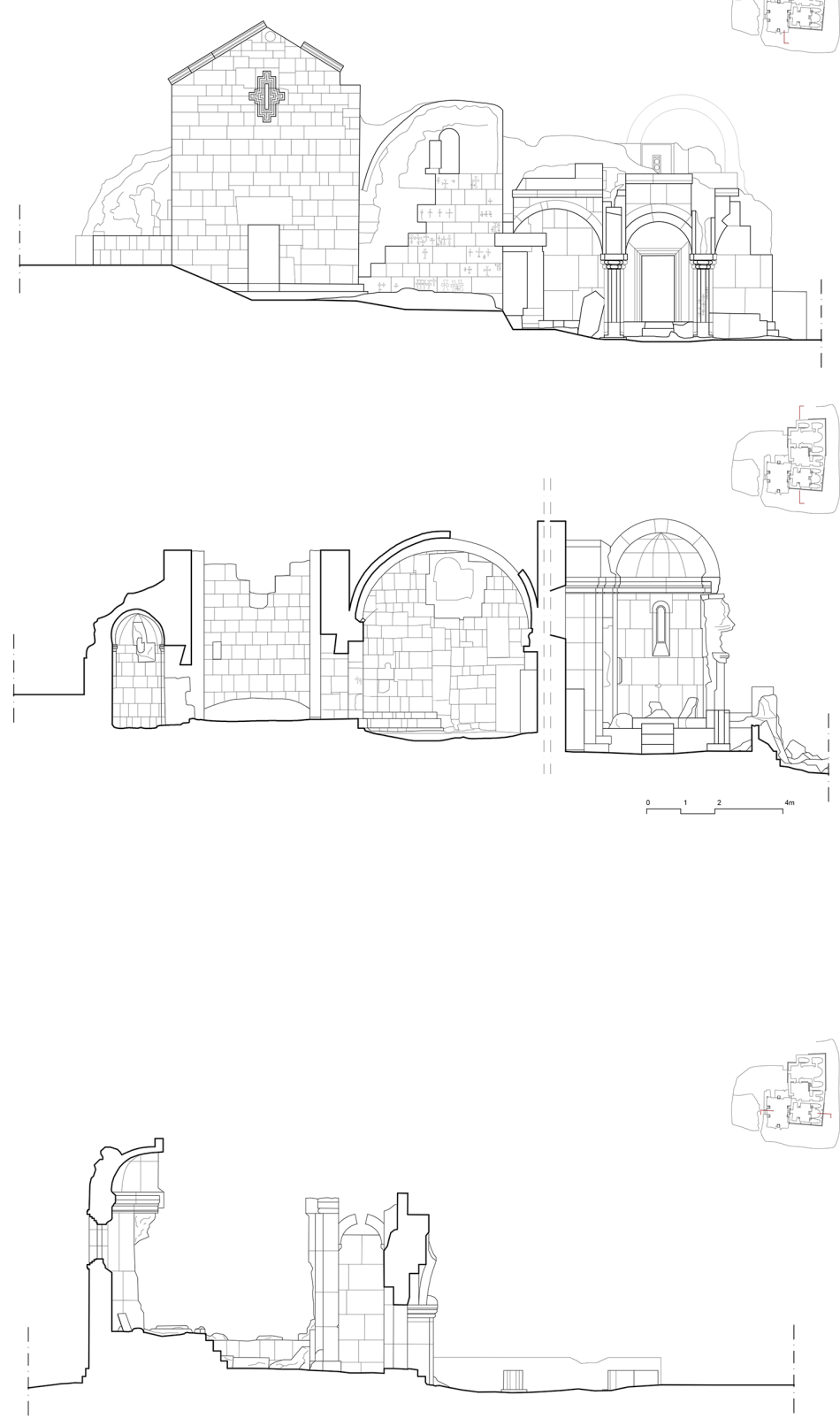

Fig. 8. Elaborati grafici,

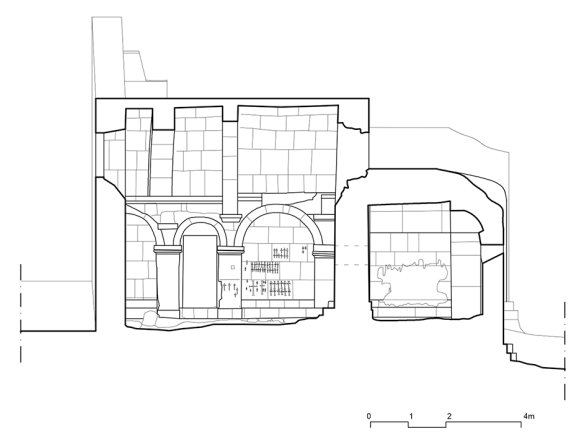

눈 


\section{Conclusioni}

Tramite questo concetto di connessione, sia del punto di vista progettuale tra territorio e architettura, sia dal punto di vista sociale con l'utilizzo di nuove tecnologie divulgative, si vuole attuare un'azione di valorizzazione e recupero della memoria locale. Si ottiene, inoltre, una maggiore possibilità di conoscenza di quei luoghi e un incremento della consapevolezza di voler e poter ricordare nel tempo quella storia che, con il passare degli anni, andrebbe invece perduta.

Nel contempo, mediante la valorizzazione e la divulgazione della memoria locale si mettono le basi per rivitalizzare il territorio rafforzando le potenzialità già presenti. Inoltre, si sviluppano nuove strategie di incremento gestionale e funzionale delle strutture architettoniche che potrebbero essere applicate anche al Monastero di Arates. In questo modo si riporterebbe il nucleo di Arates al centro del sistema di sviluppo culturale e sociale locale mediante la dislocazione di nuovi servizi dedicati come una biblioteca, sale studio e laboratori di applicazioni. Servizi volti alla ricerca ed alla conservazione dell'architettura storica armena, per conferirle nuova vita nel tempo.

\section{Note}

[I] Cuneo 1988, pp 382, 383

[2] Progetto italiano The Making of the Silk Road in Vayots Dzor. Spedizione archeologica italiana di Firenze in Armenia. Responsabile della ricerca del Dipartimento SAGAS Michele Nucciotti, responsabile della ricerca del Dipartimento DIDA C. M. R. Luschi, responsabile scientifico L. Aiello. Gruppo di lavoro per i disegni e gli studi tematici C. M. R. Luschi, L. Aiello con collaboratori anno 20 I8: A. Vezzi, N. Lecci, M. Zerbini, L. Pasqualotti, M. T. Paciolla, F. Prodi, B. Zamboni. Collaboratori anno 20 19: A. Vezzi, M. Zerbini, D. Rivetti, S. Masi, E. Oppoliti, A. Smeraldi, F. Ferrari, Giulia Galli, Marianna Mele, Fiammetta Gabbrielli

[3] Lecci, Prodi, Trovatelli, et al. 2019.

\section{Riferimenti bibliografici}

Alpago-Novello Adriano, leni Giulio, Manoukian Agopik, et al. (1988). Le Grandi Stagioni. Gli Armeni. Torino: Jaca Book.

ASIAC annual conference (20 I8). Dinamiche insediative e costruzione del paesaggio nella valle dell'Arpa (Vayotz Dzor) tra VIII e XIX secolo. Gestione e controllo del territorio sull'asse nord-sud per la Via della Seta. University of Trieste/Gorizia Campus, Gorizia: 5-7 Dicembre.

Aterini Barbara (2018). A camera obscura sundial: S. Astvazazin church in Areni, Armenia. In SCI-RESearch and Information Technology, vol. 8, Issue 2, pp. 107-120.

Cuneo Paolo (1988). Architettura Armena.Tomo I. Roma: De Luca Editore.

Cuneo Paolo (1988). Architettura Armena, dal quarto al diciannovesimo secolo. Tomo II. Roma: De Luca Editore.

Fernández-Palacios Belen Jiménez, Morabito Daniele, Remondino Fabio (2016). Access to complex reality-based 3D models using virtual reality solutions. In Journal of Cultural Heritage, n. 23, 20 I6, pp. 40-48.

Lecci Novella, Prodi Filippo, Trovatelli Francesco, et al. (2019). Experiencing Heritage Dynamic Through Visualization. II Conferenza Internazionale di Geomatica e Restauro. In The International Archives of the Photogrammetry, Remote Sensing and Spatial Information Sciences, vol. XLII-2/WII, pp. 7 I5 - 7I9.

Luschi Cecilia Maria Roberta (20 I5). The Making of the Silk Road in Armenia (C7th-Cl4th): Vayots Dzor and Arates Monastery. VII Congresso Nazionale di Archeologia Medievale. Lecce: All'Insegna Del Giglio Editore.

Luschi Cecilia Maria Roberta (20I5). La mistagogia del monastero fra sintassi teologica e composizione architettonica. Roma: Aracne Editrice.

Nucciotti Michele, Petrosyan Hamlet, Luschi Cecilia Maria Roberta et al. (2015). The Making of the Silk Road in Armenia (C7thCI 4th):Vayots Dzor and Arates Monastery. In AAVV. VII Congresso Nazionale di Archeologia Medievale. Firenze: All'Insegna Del Giglio Editore.

Velluzzi Nicola (2018). The Video Animation: An Innovative Way to Communicate. Computational Morphologies. Cham: Springer.

\section{Autore}

Alessandra Vezzi, Università degli Studi di Firenze, alessandra.vezzi@stud.unifi.it

Per citare questo capitolo:Vezzi Alessandra (2020). Strategie di valorizzazione/rivitalizzazione del patrimonio architettonico storico armeno. II caso studio di Arates/Valorization strategies/revitalization of the Armenian historical architectural heritage. The case study of Arates. In Arena A., Arena M., Brandolino R.G., Colistra D., Ginex G., Mediati D., Nucifora S., Raffa P. (a cura di). Connettere. Un disegno per annodare e tessere. Atti del $42^{\circ}$ Convegno Internazionale dei Docenti delle Discipline della Rappresentazione/Connecting. Drawing for weaving relationships. Proceedings of the 42th International Conference of Representation Disciplines Teachers. Milano: FrancoAngeli, pp. 2891-2906. 


\title{
Valorization Strategies/Revitalization of the Armenian Historical Architectural Heritage. The Case Study of Arates
}

\author{
Alessandra Vezzi
}

Abstract

This research intends to consider the potential of the conservation of local memory, through an interdisciplinary research project focused on the study of medieval buildings and the related territorial connections in the Vayots Dzor region. More precisely located in the case study of the Arates' Monastery, the foundations are laid to recover a cultural heritage that could become in the future, an opportunity for development for the country. The survey realized have allowed us to create graphic drawings that document the current state of the ruined structure. So, through this material, two types of study lines are structured: one from the design point of view linked to the interdisciplinary connections between various sectors of investigation that they work to create new design solutions between territory and architecture. The other from a social point of view, with the use of new dissemination technologies such as video and virtual reality, in order to allow a more understandable and universal reading. The aim is to develop new strategies for the management and functional increase of the architectural structures by revitalizing the Armenian historical territorial architectural heritage.

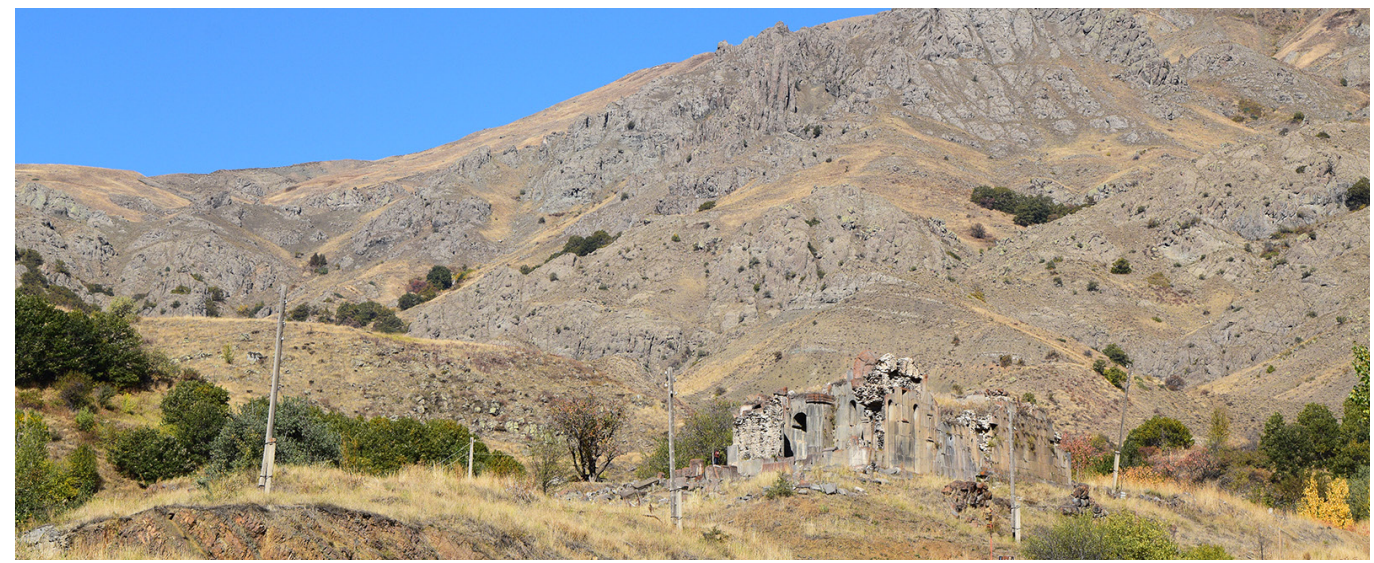




\section{Introduction}

Since 2017, the Department of Architecture (DIDA) and the Department of History, Archeology, Geography, Art and Entertainment (SAGAS) of the University of Florence have been collaborating with the University of Yerevan in an interdisciplinary study on medieval Armenian structures. The field of interest has been limited to the Vayots Dzor region whose military and religious structures of the medieval period and their territorial connections are being analyzed. All this to recover a cultural heritage that we are convinced can be the driving force of new development opportunities for the country. Preservation of the memory of these places is the basis of the research. We can therefore distinguish a line of research aimed at consolidating and increasing awareness of those territories, both from an urban and strictly architectural point of view. In this context, we present the case study of Arates, an emblematic case of an important functional center from the Middle Ages which today is completely abandoned and in disuse. Taken as a thesis object, the site presents all the qualities necessary to carry out a pilot project that triggers a new strategy of revitalization of the territory implemented through the functional location of some services.

\section{The Aretes' Monastery}

Vayots Dzor is a region south-east of Armenia characterized by valleys crossed by rivers such as the Yeghegis, Martuni and Arpa rivers, which is the main one. Along the valleys where agricultural activities are carried out, there are rural villages connected together by roads or paths that characterize the urban lattice of the territory (fig. I). Currently not everyone can afford the use of a car so it is relevant to evaluate the journey time between the different sites and any service centres. The concept of walking on foot in memory of ancient roads is still maintained today in the places of interest where, on information panels, the following are reported: the distance in $\mathrm{km}$, the time in hours of walking and the difference in height between the two closest sites to reach.

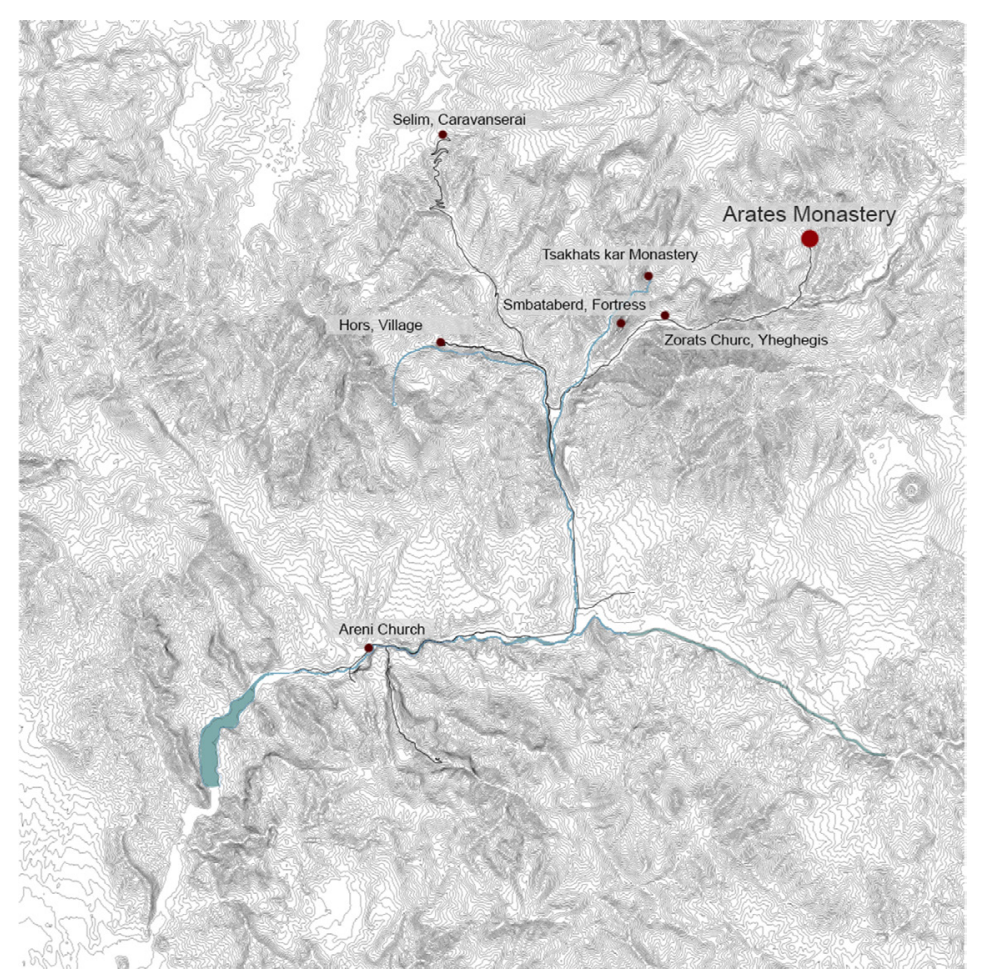


Sacred place and tourist destination, both local and foreign, is the Arates Monastery (figg. 2-5), located at $2000 \mathrm{~m}$ above sea level, located along the banks of the Martuni river at $10,8 \mathrm{~km}$ from the village of Yeghegis ( $2 \mathrm{~h}-15 \mathrm{~min}$ walk) and $4 \mathrm{~km}$ from the village of Hermon. This monastery is part of a village with low building density.

The architectural complex consists of four buildings including two churches, S. Sion and S. Astvatsatsin (Holy Mother of God), a gavit in front of the latter, now destroyed, and an intermediate vaulted area (fig. 6). The churches are placed, from north to south, side by side. S. Sion dated from Paolo Cuneo [I] between the IX and X century represents the first nucleus of the factory. It consists of a single-aisle hall with a single nave, two side chapels that flank the apse and externally conclude the plant with a straight wall. This typology confirms the presence of a monastic community that developed, during the first millennium, with the collaboration of the nearby village of Hermon developing an economy based on agriculture and livestock. Following its growth, the structure is adapted with the addition of new building parts.

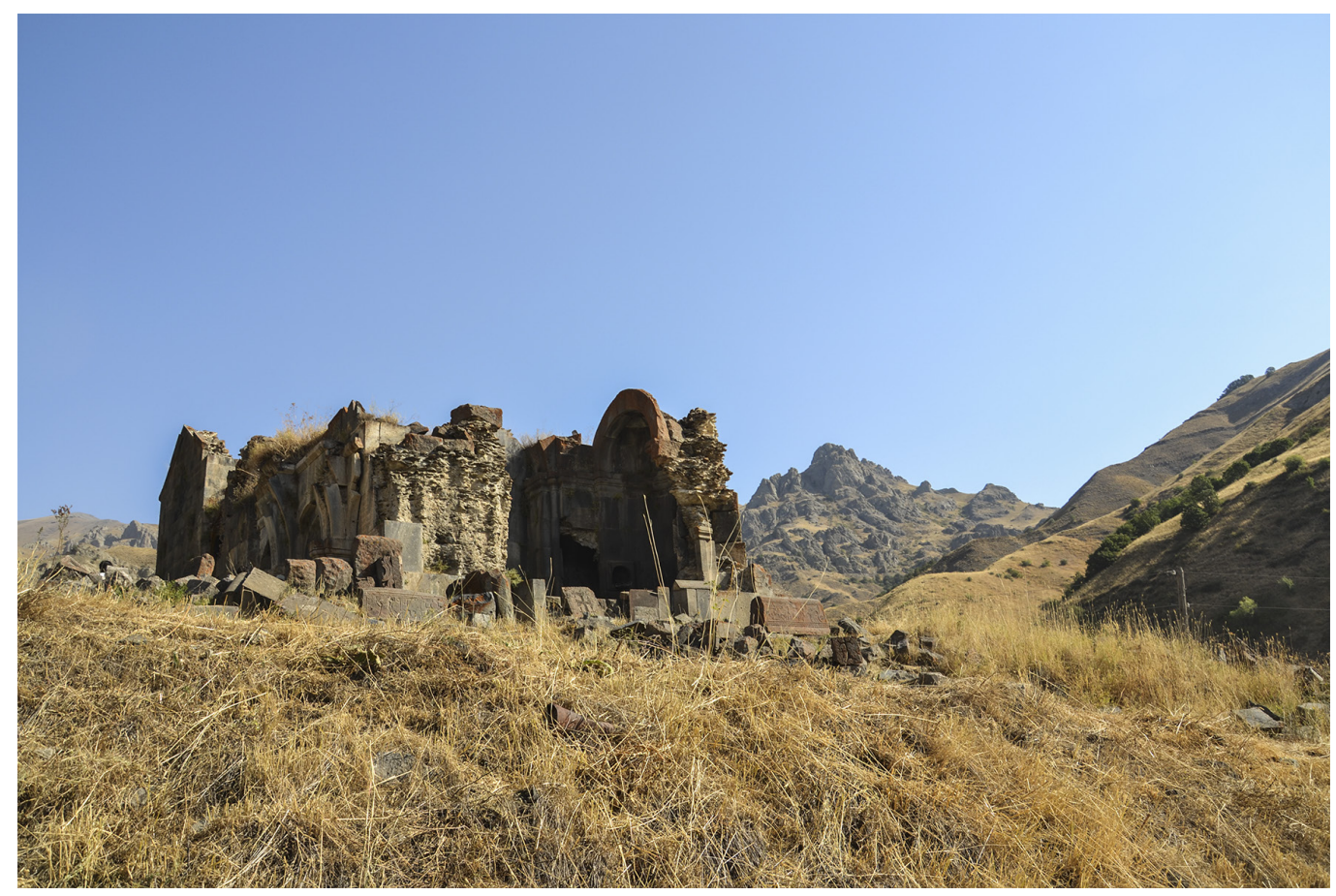

The subsequent expansion is $\mathrm{S}$. Astvatsatsin dated between the mid- $\mathrm{XI}$ century, on the other hand, is a church with a central domed hall. The vaults that once supported the dome rested on a pair of walls, which remained intact, against the north and south sides of the church itself. The apse is flanked by two chapels, one of which has remained almost completely intact while the other remains only the base with the first row of slabs. The entrances to the churches face west.

The gavit, whose construction dates back to 1270, during the period of the Orbelian dynasty, is the space in front of the church of S. Astvatsatsin with the function of welcomes the lay community of the faithful who during the celebrations, could not access to the sacred space. Also represents a structure, which has now collapsed, supported on pillars with an eye opening in the center in the cover. In its paved pavement there are sepulchral gravestones.

Finally, the intermediate area between the two churches has an almost square irregular plan connected to two chapels on the east side. The complex is in a state of disrepair and a large part of the monastery has collapsed, leaving visible the internal structure of the wall. 


\section{Project's connections}

The important campaigns conducted by the Faculty of Architecture of Florence in 2018 and 2019 [2] have made it possible to create graphic designs that document the current state of the structure Figs. 7, 8). The direct survey and photographic campaigns have allowed a reconstruction of the artifact that served and will serve as a support for all the analyzes that the monument still needs. Working in a multidisciplinary team, the work was in fact structured and aimed at the different areas of investigation: archaeological (for the stratigraphic reading of the construction phases),architectural (for the understanding of the design matrices itself and as a support for a conservation proposal and design redevelopment) and structural (to analyze their seismic susceptibility and implement the right intervention actions).

Through plans, elevations and sections in the appropriate scale, an architecture, has been made accessible on which specialist studies can be applied. We can therefore speak of design connections between the various areas of study which together contribute to having an accurate and significant result on the building under consideration.

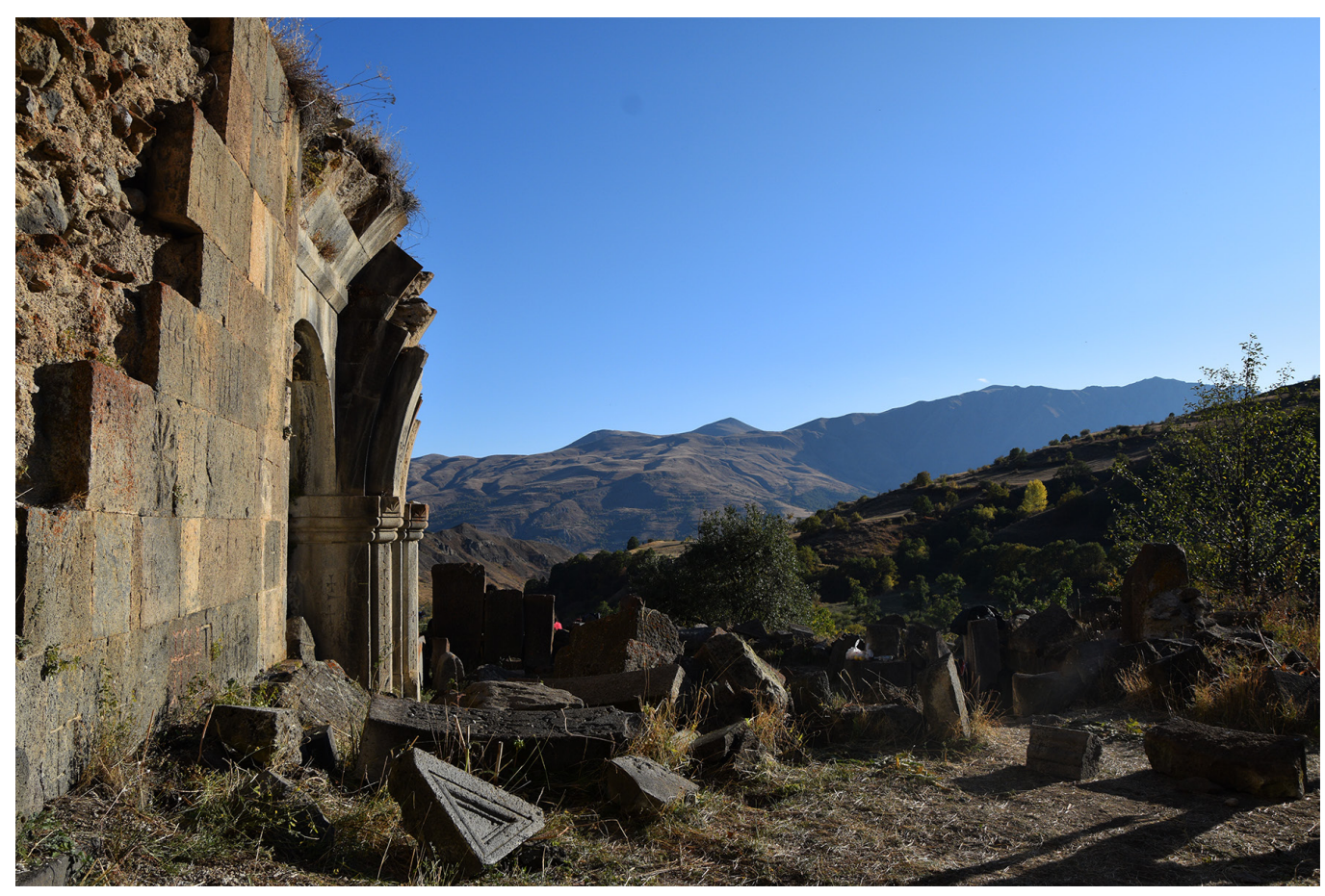

All this information provides a basis for a possible consolidation and restoration until reaching design solutions that have their roots in the history of the place. Talking about the latter, the massive architectural culture of sacred buildings must be taken into consideration, characterized by ashlars in square stone in the color of the surrounding mountains in which the existing structure is confused. We observe in this context the importance of using local materials, such as wood and stone from the surrounding cave.

Being able to dialogue with the various differences in terrain that surround the construct and characterize it, means find a dialogue with the same genius loci that must have inspired the medieval builder. In this way, we try to nourish the memory of the place, that preserves what already exists but, at the same time, through a new refunctionalization project, we try to renew and make usable an architecture that can overcome time by regaining its role of functional attractor. 


\section{Social's connections}

Remaining in the specific field of communication of a project, we highlight that the representation of the architectural space, usually expressed through two-dimensional drawings, is optimal for sector experts but not for external individuals who have difficulty viewing the space. In a context of preliminary disclosure in the processing data research is therefore important to use technologies [3], as territorial and individual building three-dimensional models that can allow a more understandable reading capable of involving all types of observer through a new information approach.

For the realization of the 3D model of the surrounding area, is used a shp file containing the level curves required on a single plane, to which the heights are attributed in the QGis software. While for the 3D model of the building to be analyzed, it is essential to use the integration between direct and indirect survey (digital photogrammetry) depending on the available equipment and the difficulty of accessing the sites, obtaining a mesh or nurbs model if geometrically reconstructed. Finally, the two three-dimensional models can be integrated using a coordinate system of the architecture examined. In this way, is obtained a model more appropriate for popular purposes is obtained while maintaining the scientific technical characteristics.

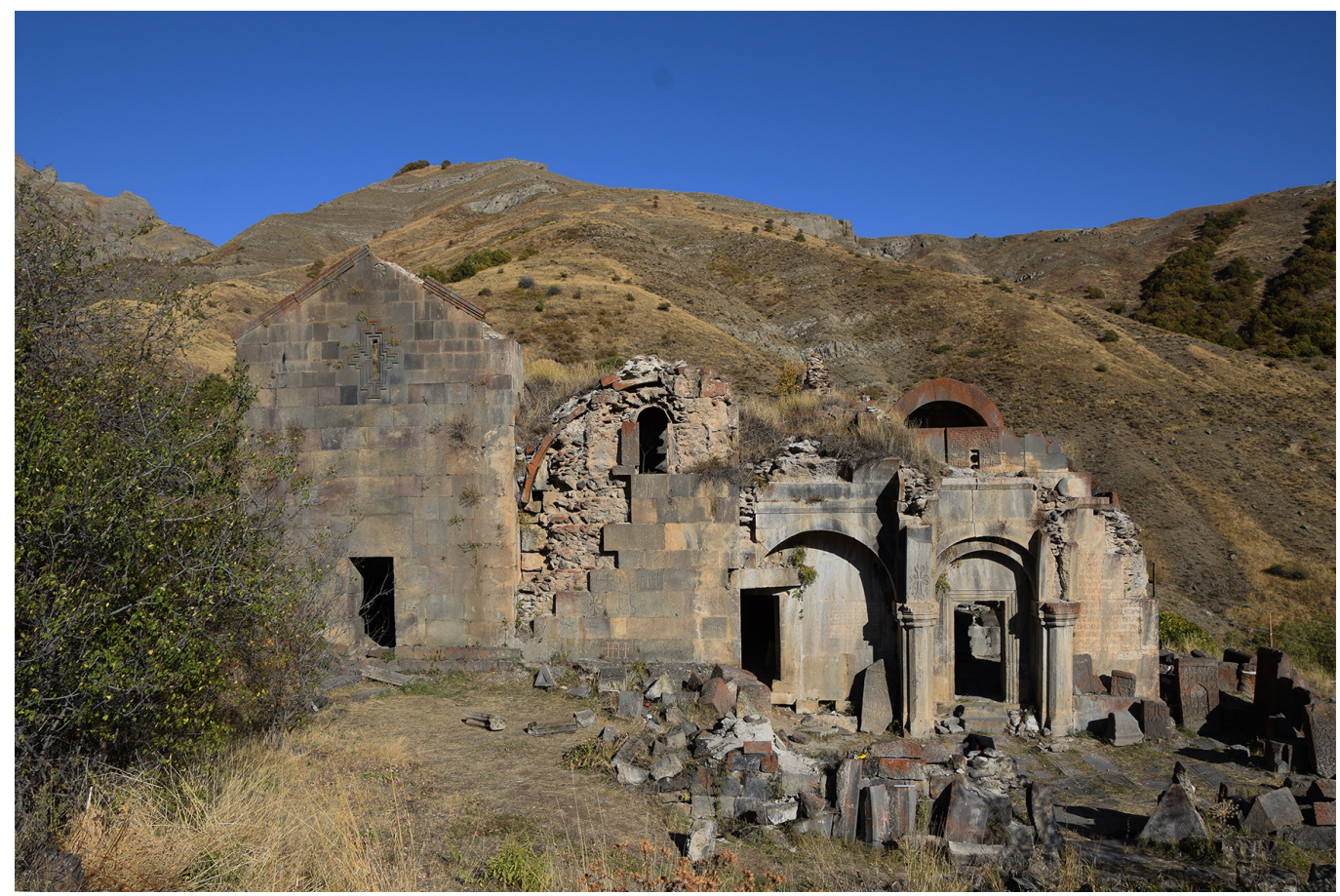

The aim is to spread the models through three display systems such as: video and virtual reality. Through the video, the viewer is guided by an animation through different framing chosen by the director that identify a path: wider and environmental framing, when it comes to showing the territory and more precise framing when you want to indicate an architectural building in more detail. In virtual reality (VR), however, the point of view is that of the observer who is inserted in a scenery created on the computer, and therefore virtual, becoming the protagonist of a new reality. 
Fig. 5. Territorial framework of Arates' Monastery (in red).
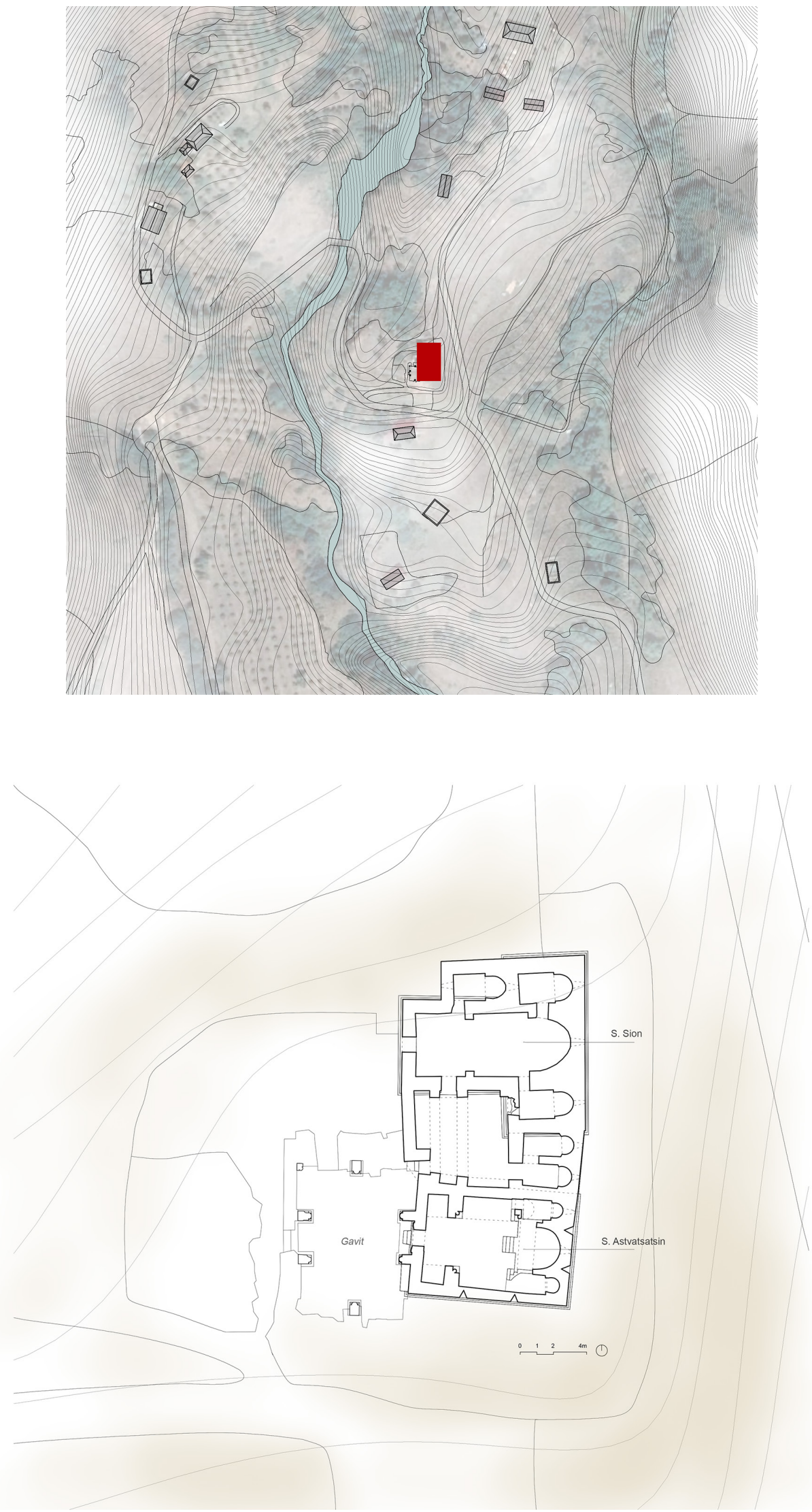

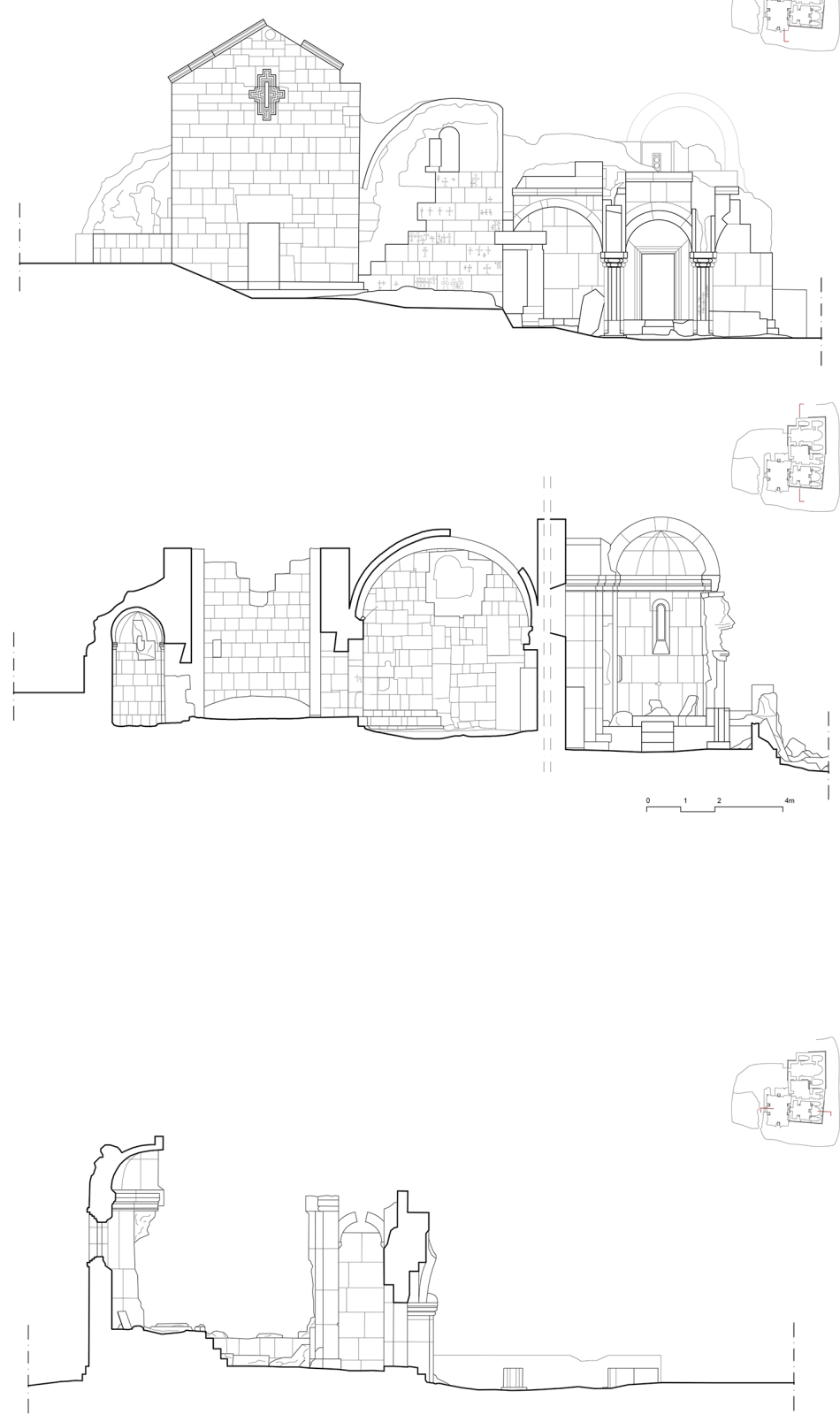

Fig. 8. Graphic drawings,

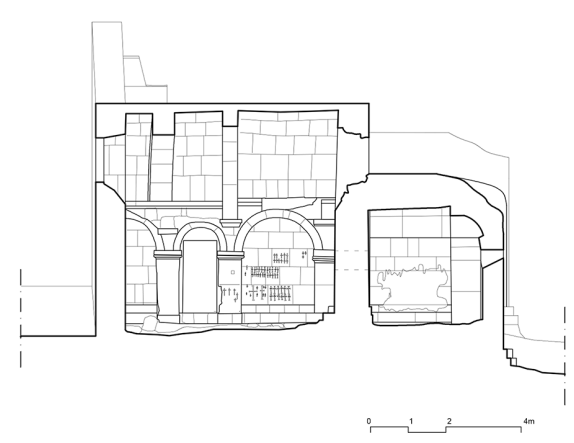

눈 


\section{Conclusions}

Through this concept of connection, both from the design point of view between the territory and architecture, and from the social point of view with the use of new dissemination technologies, we want to implement an action of enhancement and restoration of local memory. You also get a greater chance of knowing those places and an increase in awareness of wanting and being able to remember over time that story that, over the years, would instead be lost.

At the same time, through the enhancement and dissemination of local memory, the foundations are laid to revitalize the territory by strengthening the potential already present. Moreover, new strategies for the management and functional increase of the architectural structures are being developed which could also be applied to the Arates Monastery. This would bring the focal point of Arates back to the center of the local cultural and social development system by relocating new dedicated services such as a library, study rooms, application laboratories. These are services aimed at the research and conservation of Armenian historical architecture giving it new life in order to last over time.

\section{Notes}

[I] Cuneo 1988, pp 382, 383

[2] Italian Project, The Making of the Silk Road in Vayots Dzor. Italian archaeological expedition of Florence in Armenia. Head of research of the Department SAGAS Michele Nucciotti, head of Research of the Department DIDA C. M. R. Luschi, scientific manager L. Aiello. Working group for drawings and thematic studies:C. M. R. Luschi, L. Aiello with collaborators year anno 20 I 8 : A. Vezzi, N. Lecci, M. Zerbini, L. Pasqualotti, M. T. Paciolla, F. Prodi, B. Zamboni. Collaborators year 20 I 9: A. Vezzi, M. Zerbini, D. Rivetti, S. Masi, E. Oppoliti, A. Smeraldi, F. Ferrari, Giulia Galli, Marianna Mele, Fiammetta Gabbrielli.

[3] Lecci, Prodi, Trovatelli, et al. 2019.

\section{References}

Alpago-Novello Adriano, leni Giulio, Manoukian Agopik, et al. (1988). Le Grandi Stagioni. Gli Armeni. Torino: Jaca Book.

ASIAC annual conference (20।8). Dinamiche insediative e costruzione del paesaggio nella valle dell'Arpa (Vayotz Dzor) tra VIII e XIX secolo. Gestione e controllo del territorio sull'asse nord-sud per la Via della Seta. University of Trieste/Gorizia Campus, Gorizia: 5-7 Dicembre.

Aterini Barbara (2018). A camera obscura sundial: S. Astvazazin church in Areni, Armenia. In SCl-RESearch and Information Technology, vol. 8, Issue 2, pp. I07-120.

Cuneo Paolo (1988). Architettura Armena.Tomo I. Roma: De Luca Editore.

Cuneo Paolo (1988). Architettura Armena, dal quarto al diciannovesimo secolo. Tomo II. Roma: De Luca Editore.

Fernández-Palacios Belen Jiménez, Morabito Daniele, Remondino Fabio (20 I 6). Access to complex reality-based 3D models using virtual reality solutions. In Journal of Cultural Heritage, n. 23, 2016, pp. 40-48.

Lecci Novella, Prodi Filippo, Trovatelli Francesco, et al. (2019). Experiencing Heritage Dynamic Through Visualization. II Conferenza Internazionale di Geomatica e Restauro. InThe International Archives of the Photogrammetry, Remote Sensing and Spatial Information Sciences, vol. XLII-2MII, pp. 715 - 719.

Luschi Cecilia Maria Roberta (20I5). The Making of the Silk Road in Armenia (C7th-Cl4th): Vayots Dzor and Arates Monastery. VII Congresso Nazionale di Archeologia Medievale. Lecce: All'Insegna Del Giglio Editore.

Luschi Cecilia Maria Roberta (2015). La mistagogia del monastero fra sintassi teologica e composizione architettonica. Roma: Aracne Editrice.

Nucciotti Michele, Petrosyan Hamlet, Luschi Cecilia Maria Roberta et al. (20 I5). The Making of the Silk Road in Armenia (C7thCI 4th): Vayots Dzor and Arates Monastery. In AAVV. VII Congresso Nazionale di Archeologia Medievale. Firenze: All'Insegna Del Giglio Editore.

Velluzzi Nicola (2018). The Video Animation: An Innovative Way to Communicate. Computational Morphologies. Cham: Springer.

Author

Alessandra Vezzi, Università degli Studi di Firenze, alessandra.vezzi@stud.unifi.it

To cite this chapter:Vezzi Alessandra (2020). Strategie di valorizzazione/rivitalizzazione del patrimonio architettonico storico armeno. II caso studio di Arates/Valorization strategies/revitalization of the Armenian historical architectural heritage. The case study of Arates. In Arena A., Arena M., Brandolino R.G., Colistra D., Ginex G., Mediati D., Nucifora S., Raffa P. (a cura di). Connettere. Un disegno per annodare e tessere. Atti del $42^{\circ}$ Convegno Internazionale dei Docenti delle Discipline della Rappresentazione/Connecting. Drawing for weaving relationships. Proceedings of the 42th International Conference of Representation Disciplines Teachers. Milano: FrancoAngeli, pp. 2891-2906. 